\title{
Synthesis and Characterization of PtRu/C Catalysts Obtained by Colloidal and Deposition Methods for Fuel Cell Applications
}

\author{
Egberto Gomes Franco ${ }^{\mathrm{a}, \mathrm{c}, \mathrm{d}, \mathrm{e}}$, Almir Oliveira-Neto ${ }^{\mathrm{a}}$,Estevam Vitório Spinacéa, Marcelo Linardi**, \\ Nathalie Martz, Marian Mazurek ${ }^{\mathrm{b}}$, Hartmut Fuess ${ }^{\mathrm{b}}$ \\ anstituto de Pesquisas Energéticas e Nucleares - IPEN/CNEN - SP, Brazil \\ ${ }^{\mathrm{b}}$ Technical University of Darmstadt, Germany \\ ${ }^{\mathrm{c}}$ Universidade Bandeirante de São Paulo, Brazil \\ ${ }^{\mathrm{d}}$ Centro de Ensino Superior de Barueri, Brazil \\ ${ }^{\mathrm{e}}$ Faculdades Ítalo-Brasileira, Brazil
}

Received: November 23, 2003; Revised: February 1, 2005

\begin{abstract}
The purpose of this investigation was to compare catalysts produced by the Bönnemann - colloidal method (PtRu (B1) and PtRu (B2)), and those produced by the spontaneous deposition method (PtRu (SD)). The catalysts produced by both methods had good electrochemical behavior for methanol oxidation for proton exchange membrane fuel cell applications. The structure of the catalyst was examined by transmission electron microscopy (TEM). Energy dispersive spectroscopic analysis (EDS) was used to determine the semi-quantitative composition of the catalysts, and the electrochemical behavior was determined by cyclic voltammetry $(\mathrm{CV})$. The diffractograms of the binary catalysts revealed platinum and ruthenium as the only crystalline phases, as per ICDD data base. The PtRu (B1) catalyst, treated in a reducing atmosphere, has the same structure as PtRu (B2), treated in an oxidising/reducing atmosphere, except that the crystallite size was around $1.7 \mathrm{~nm}$ for PtRu (B1) instead of $9.9 \mathrm{~nm}$ for PtRu (B2). The catalysts PtRu (B2) and $\mathrm{PtRu}(\mathrm{SD})$ showed similar cyclic voltammetric behavior, which was better than that of PtRu (B1).

Both methods are suitable for the production of electrocatalysts for fuel cell applications. The colloidal method is more expensive than the deposition method, but the former permits the production of ternary and quaternary catalyst systems with enhanced $\mathrm{CO}$ tolerance.
\end{abstract}

Keywords: fuel cell, catalyst, methanol, electrocatalyst, nanocrystal

\section{Introduction}

Sustainable development is one of the main concerns of industry in this century. Nevertheless, fuel cell technology has a promising future in the field of electricity generation with less environmental impact ${ }^{1}$.

One of the most important areas in fuel cell research is the development of new catalysts to increase electroactivity related to $\mathrm{H}_{2} / \mathrm{CO}$, methanol and ethanol oxidation. To minimize contamination caused by $\mathrm{CO}$ adsorption on $\mathrm{Pt}$ sites, different techniques for synthesizing catalysts have been reported in the literature ${ }^{2-4}$. In this investigation different catalysts have been synthesized by two different methods: the Bönneman ${ }^{5}$ method and spontaneous deposition ${ }^{6-8}$.

$\mathrm{X}$-ray diffraction (XRD)analysis, transmission electron microscopy (TEM), energy dispersive spectroscopic analysis (EDS) and cyclic voltammetry $(\mathrm{CV})$ were used to characterize the structure and electrochemical activity of the catalysts.

The synthesis of catalysts has been investigated widely ${ }^{8}$ and it is well known that the different methods of synthesis lead to different behavior in the catalysts. In this context, a lot of work has been done to correlate the electrochemical behavior of the electrocatalyst and its structure.

Two different methods were selected to synthesize the electrocatalysts. The Bönnemann's method was selected for doping the carbon black (electrode material) with the electrocatalyst, in a modified manner ${ }^{9}$, which consisted of a colloidal system in a dry nitrogen atmosphere, and used anhydrous solvents and salts of the metals. The Bönnemann method gives a crystallite, with an average size between 1.5 to $3.0 \mathrm{~nm}$, that is well dispersed in the carbon matrix ${ }^{10}$. The spontaneous deposition method was the other method, and consisted in the spontaneous deposition of a monolayer of platinum on the surface of the ruthenium support. This method was chosen because it gives a high electroactivity, per gram of platinum used. Catalysts obtained by both methods showed interesting electrochemical behavior.

\section{Experimental}

\subsection{Bönnemann's method}

To obtain the nanocrystal, a stable colloid should be prepared in an inert and dry atmosphere. The proper amounts of chloride salts of the metals involved were dissolved in anhydrous tetrahydrofuran (THF) with a proper amount of tetraoctilamoniyoum bromide $\left[\mathrm{N}(\mathrm{oct})_{4} \mathrm{Br}\right]$, while the reducing agent was prepared by the dissolution of tetraoctilamoniyoum bromide $\left[\mathrm{N}(\mathrm{oct}){ }_{4} \mathrm{Br}\right]$ in THF, by adding potassium trietilhydroborate $\left[\mathrm{KHBr}(\mathrm{Et})_{3}\right]$. After stirring, a strong reducing agent is formed (trietilhydroborate of tetraoctilamonyoum $\left.\left[\mathrm{N}(\mathrm{oct})_{4} \mathrm{HBr}(\mathrm{Et})_{3}\right]\right)$ according to Equation 1:

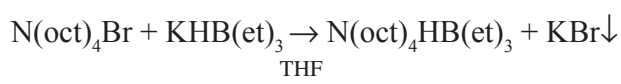

To reduce the metallic ions, 1.5 times the stoichiometric amount of reducing agent $\left[\mathrm{N}(\mathrm{oct})_{4} \mathrm{HBr}(\mathrm{Et})_{3}\right]$ was used. This was added to the solution of metals salts and heated under stirring. The reduction is followed by the extent of darkening of the solution and hydrogen evolution, as shown in Equation 2. 
$\mathrm{MeX}_{\mathrm{n}}+\mathrm{N}(\text { oct })_{4} \mathrm{HB}(\mathrm{et})_{3} \rightarrow \mathrm{Me}^{*}\left[\mathrm{~N}(\text { oct })_{4}\right]^{+}+\mathrm{nB}(\mathrm{et})_{3}+$

$\mathrm{n} / 2 \mathrm{H}_{2} \uparrow+\mathrm{nX}^{-} \quad$ THF colloid

Adsorption of the $\left[\mathrm{N}(\mathrm{oct})_{4}\right]^{+}$ion on the metallic surface forms the stable colloid with an average size of 1.5 to $3.0 \mathrm{~nm}$. Up to this point all the steps are performed in an inert and dry atmosphere. The stable colloid is shown schematically in Figure 1.

After synthesis of the stable colloid, a suspension of the Vulcan carbon black in THF was prepared and the colloid solution added drop wise. The final stages in the preparation of the electrocatalyst consisted of filtration followed by multiple rinsing in THF and ethanol.

\subsection{Spontaneous deposition}

This method was recently reported by Adzic et al. ${ }^{6-8}$ to help minimize the amount of platinum used to synthesize the PtRu catalyst. According to the authors, only a quarter of a monolayer of platinum on ruthenium nanocrystals results in an electrocatalyst with higher activity and tolerance to $\mathrm{CO}$ poisoning of the platinum sites by $\mathrm{H}_{2} / \mathrm{CO}$ oxidation, compared to commercial catalysts of PtRu alloys.

To obtain an electrocatalyst with $20 \mathrm{wt}$. (\%) of ruthenium, carbon support (Vulcan XC-72R) was impregnated with a solution of $\mathrm{RuCl}_{3} \cdot 1.5 \mathrm{H}_{2} \mathrm{O}$ (Aldrich) in water: ethanol $(1: 1, \mathrm{v} / \mathrm{v})$ and dried at $343 \mathrm{~K}$ for 4 hours. The solids obtained were heated from room temperature to $673 \mathrm{~K}$ at $1 \mathrm{~K} \mathrm{~min}^{-1}$ in a flowing argon atmosphere. Upon reaching the temperature, hydrogen gas was introduced and the sample was held at this temperature for 2 hours. The sample was then cooled to room temperature under flowing hydrogen and then immersed in an aqueous solution of $\mathrm{H}_{2} \mathrm{PtCl}_{6}\left(0.01 \mathrm{~mol} \mathrm{~L}^{-1}\right)$ held in an argon atmosphere. The mixture was stirred for 15 minutes, filtered, washed thoroughly with water and dried at $343 \mathrm{~K}$ for 3 hours.

\subsection{Structural characterization of the electrocatalyst powder by EDX, XRD and HRTEM.}

A Philips XL 30 scanning electron microscope with EDX was used to examine the morphology of the powder and to determine the semi-quantitative composition of the catalyst powder.

X-ray powder diffraction analysis was carried out in a STOE STADIP powder diffractometer, with germanium monochromatized $\mathrm{CuK}_{\alpha}$ radia-

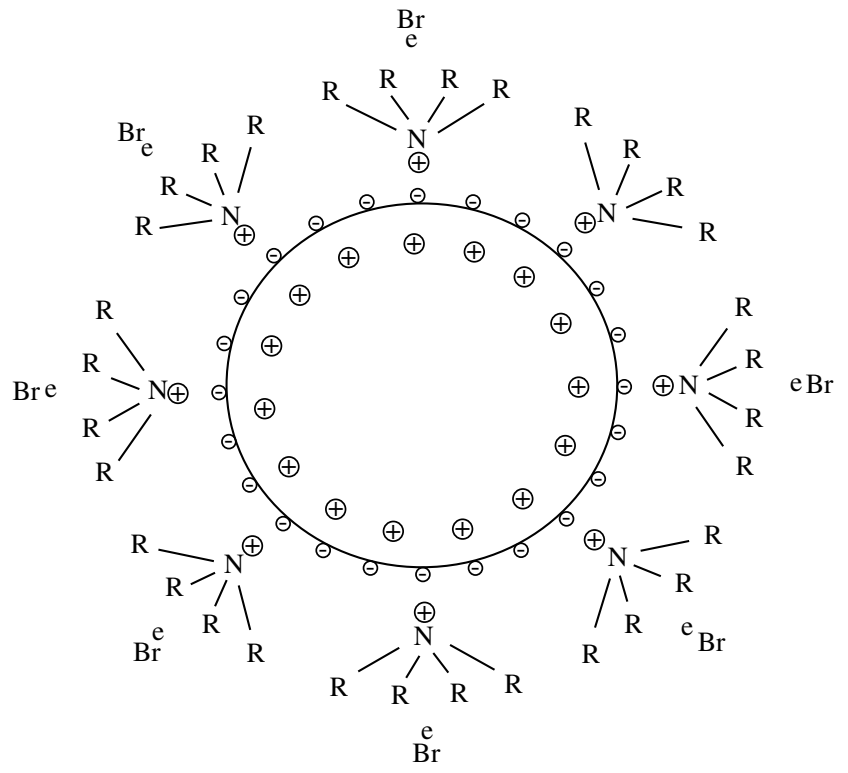

Figure 1. Schematic figure of a colloid 5 . tion and a position-sensitive detector with $40^{\circ}$ aperture in the transmission mode, with $2 \theta$ scanned from 10 to $90^{\circ}$ at a scan rate of $0.03^{\circ} \mathrm{s}^{-1}$.

A Philips CM 20 transmission electron microscope (TEM) with an acceleration voltage of $200 \mathrm{kV}$ and a tungsten cathode was used to obtain high resolution images of the catalysts. The microscope was equipped with a nano-EDX device to determine the catalyst's composition in nm-sized regions. The TEM samples were prepared by suspending the catalyst powder in methanol and depositing a drop of the suspension on a standard copper grid covered with carbon. These analyses, (XRD and HRTEM) were carried out at the Materials Science Institute of the Technical University of Darmstadt.

\subsection{Electrochemical investigations}

The electrochemical investigations consisted of cyclic voltammetry (CV) with an EGG Princeton Applied Research Model 273 in a $\mathrm{N}_{2}$ saturated $0.5 \mathrm{~mol} \mathrm{~L}^{-1} \mathrm{H}_{2} \mathrm{SO}_{4}$. Methanol oxidation was evaluated with solutions containing three different concentrations of methanol, $0.1 \mathrm{~mol} \mathrm{~L}^{-1}, 0.5 \mathrm{~mol} \mathrm{~L}^{-1}, 1.0 \mathrm{~mol} \mathrm{~L}^{-1}$, at $25^{\circ} \mathrm{C}$. The working electrode consisted of a thin porous layer of the catalyst as dispersed nanoparticles in carbon black with a high surface area. The reference electrode was a RHE and the counter electrode was a platinized Pt plate. As reported earlier, the electrocatalyst produced by the Bönnemann`s method usually contains some adsorbed species from the protective shell formed around the colloid ${ }^{11}$. These species block the active platinum sites. Despite this, a heat treatment in a reducing atmosphere $\left(\mathrm{H}_{2}\right)$ improves the electroactivity of the catalysts. Neto et al. ${ }^{12}$ reported that PtRuNi electrocatalysts prepared by the Bönnemann method and then heat treated showed higher electroactivity than the same catalysts without heat treatment. The cyclic voltammetric results revealed that the heat treated catalyst exhibited improved electroactivity. This heat treatment was carried out in a nitrogen/hydrogen atmosphere for 2 hours at $300{ }^{\circ} \mathrm{C}$, followed by furnace cooling ${ }^{13}$. Another heat treatment was also carried out with the Bönnemam catalysts, which used oxidising and reducing atmospheres ${ }^{14,15}$ at $300^{\circ} \mathrm{C}$. The heat treatment was first carried out in an inert atmosphere until the catalysts reached $300{ }^{\circ} \mathrm{C}$. Subsequently a small flow of oxygen was used for 20 minutes and this was followed by hydrogen for 2 hours.

\section{Results}

In order to simplify, the catalysts synthesized by the Bönneman's method and heat treated in the reducing atmosphere is labeled as $\mathrm{PtRu}(\mathrm{B} 1)$, while the catalyst heat treated in the oxidizing/reducing atmosphere is labeled as PtRu (B2). The catalyst synthesized by spontaneous deposition is labeled as $\mathrm{PtRu}(\mathrm{SD})$.

\subsection{Catalyst composition}

The compositions of the catalysts were determined by EDX and the results are presented in Table 1 .

The compositions of the catalysts synthesized by the Bönnemann method are in agreement with the experimental procedure. The composition of the catalyst obtained by the spontaneous deposition method reveals the presence of a small amount of platinum on the surface of the ruthenium supported-nanocrystals.

\section{2. $X$-ray diffraction $(X R D)$}

The diffractograms of the binary catalysts reveal platinum and

Table 1. Atomic ratios of $\mathrm{Pt}$ and $\mathrm{Ru}$ in the electrocatalysts.

\begin{tabular}{lccc}
\hline Element & PtRu (B1) & PtRu (B2) & PtRu (SD) \\
\hline Platinum & 59 & 59 & 10 \\
Ruthenium & 41 & 41 & 90 \\
\hline
\end{tabular}


ruthenium as the only crystalline phases, as per the ICDD data base. No evidence of other metallic phases or crystalline oxide species was found. Almost complete reduction of the educts was achieved, as no reflections of any metal chlorides appear in the patterns. The diffractograms can be seen in Figure 2.

A major difference can be observed between the results of the catalysts PtRu (B1) and PtRu (B2). As both the catalysts were produced in the same batch, one can conclude that the only difference is the heat treatment procedure. The average crystallite size seems to increase in the following order: PtRu (B1) $<$ PtRu (SD) $<$ PtRu (B2). This result is in agreement with the high-resolution micrographs of the catalysts (Figures 3 and 4). The diffractogram of the support (Vulcan carbon black) indicates that the peaks with $2 \theta$ around 24.520, 43.4 and 79.780 are influenced by the carbon support. The diffractograms of the binary catalysts reveal platinum and ruthenium as the only crystalline phases as per the ICDD database. No evidence of other metallic phases or crystalline oxide species was found. Almost complete reduction of the educts was achieved, as no reflections of any metal chlorides appear in the patterns of the catalysts synthesized by the Bönnemann method. These results are in good agreement with data reported by Radmilovic et al. ${ }^{16}$ and others ${ }^{17-19}$.

Despite the fact that a majority of the authors agree about the use of X-ray diffraction for analysis, Rolinson et al. ${ }^{20}$ state that X-ray diffraction is not a suitable method to characterize the phases in catalysts. Rolinson stressed that XRD measurements indicate the presence of Pt (FCC) phase only, but by using TGA/DTA and XPS measurements, the results indicate that the catalyst is composed of hydrated and unhydrated ruthenium oxides, that could be amorphous ${ }^{20}$.

\subsection{High-resolution transmission electron microscopy (HRTEM)}

Nanocrystallites of catalysts PtRu (SD) and PtRu (B2) are shown in Figures 3 and 4. The catalytically active particles are well dispersed on the support grains in both samples. Compared to results published by Schmidt et al. ${ }^{14}$ for PtRu, bigger crystallites were observed in catalysts synthesized by the Bönnemann method and heat treated with oxidising/reducing atmospheres. Similar growth in crystallite size was observed in the case of samples prepared by the spontaneous deposition method, but to a lesser extent. The HRTEM results are in good agreement with the shape of the diffractograms of the 3 samples. The first catalyst, PtRu (B1), has a small crystallite size that is difficult to resolve by XRD, the second catalyst with the largest crystallites, are in good agreement with the FWHM for this catalyst and the third catalyst had medium sized crystallites and some agglomerates. The catalyst PtRu (B1) has been described in the literature to have an average size of $1.7 \mathrm{~nm}^{21}$.

The PtRu (B1) catalyst has the same structure as that of PtRu (B2), except that the crystallite size is around $1.7 \mathrm{~nm}$ instead of $9.9 \mathrm{~nm}$. The nanocrystals are well dispersed on the carbon support, similar to PtRu (B1).

\subsection{Cyclic voltammetry $(C V)$}

The three catalysts were tested by cyclic voltammetry to evaluate their electrochemical activity. Cyclic voltammetry was performed with sulfuric acid $\left(\mathrm{H}_{2} \mathrm{SO}_{4} 0.5 \mathrm{~mol} \mathrm{~L}^{-1}\right)$ as a support electrolyte and to record the basic voltamogram of each catalyst. After this, other voltamograms were recorded as a function of methanol concentrations, $0.1 \mathrm{~mol} \mathrm{~L}^{-1}, 0.5 \mathrm{~mol} \mathrm{~L}^{-1}$ e $1.0 \mathrm{~mol} \mathrm{~L}^{-1}$. To compare the results, voltamograms corresponding to methanol concentration of $1.0 \mathrm{~mol} \mathrm{~L}^{-1}$ were chosen because this is the concentration often used in fuel cell operation. A scan rate of $10 \mathrm{mV} \mathrm{s}^{-1}$ was used in the experiments.

The results of electrooxidation of methanol with these catalysts are shown in Figure 5.

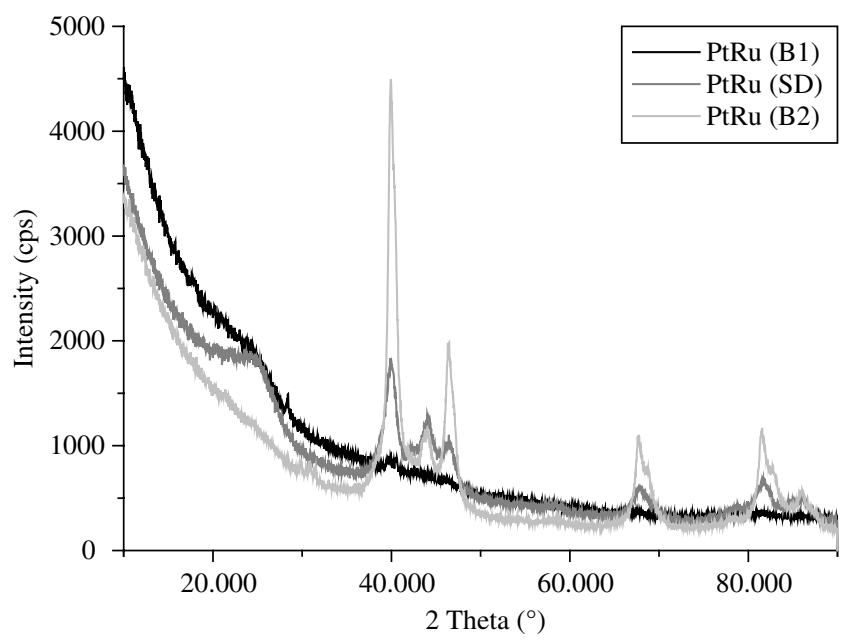

Figure 2. Diffractograms of the catalysts PtRu (B1), PtRu (B2) and PtRu (SD).

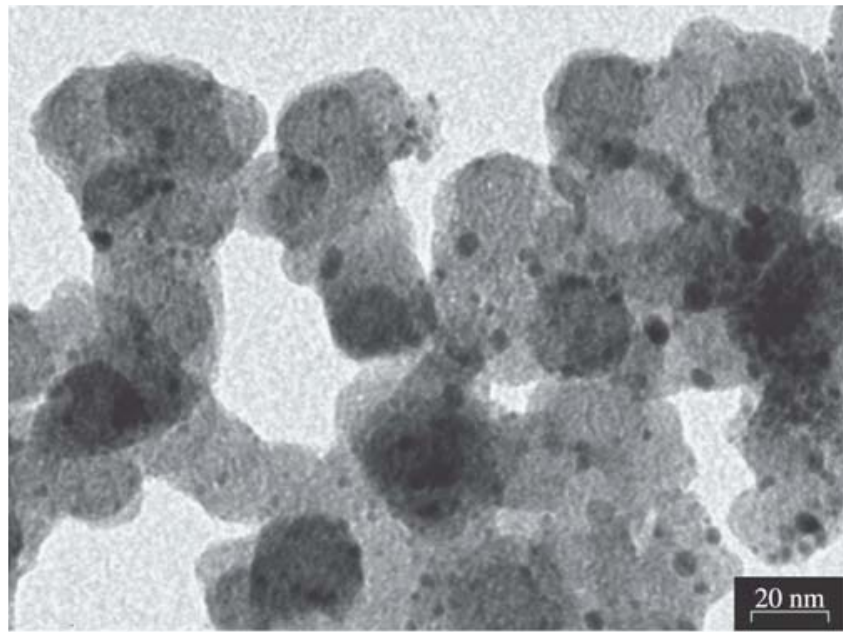

Figure 3. Nanocrystals of PtRu (SD) electrocatalyst dispersed in the carbon matrix. The crystallites have a bimodal distribution with an average size of $2.5 \pm 0.4 \mathrm{~nm}$ and $5.2 \pm 1.2 \mathrm{~nm}$

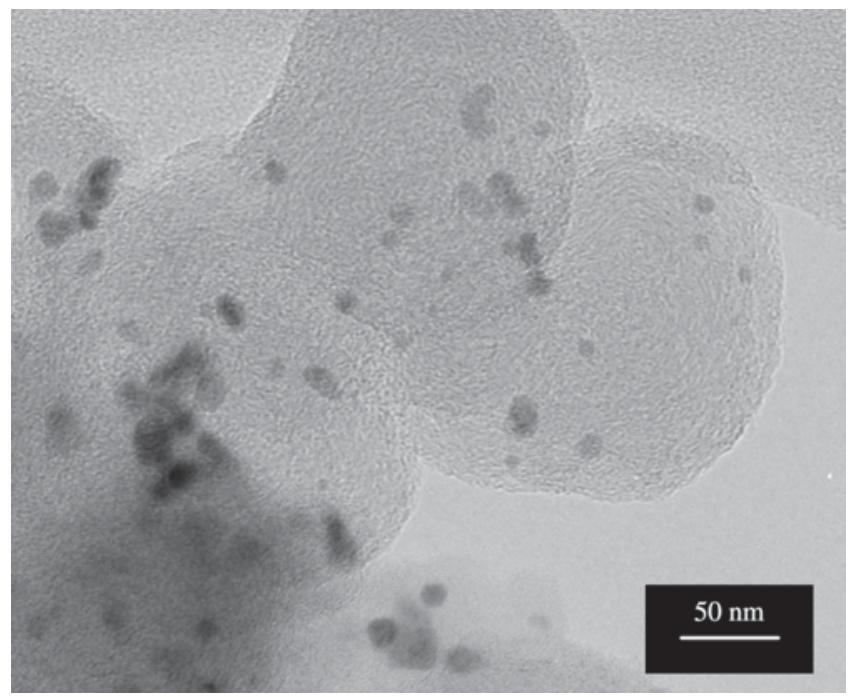

Figure 4. Nanocrystals of PtRu (B2) electrocatalyst, well dispersed in the carbon matrix, but with an average crystallite size of $9.9 \pm 2.5 \mathrm{~nm}$. 


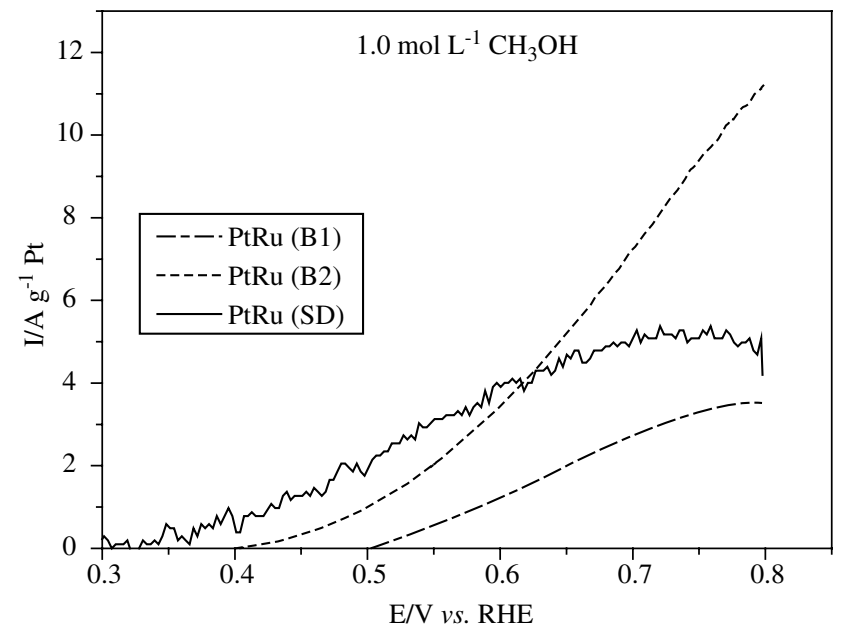

Figure 5. Oxidation of methanol in a $1.0 \mathrm{~mol} \mathrm{~L}^{-1}$ methanol solution at scan rate of $10 \mathrm{mVs}^{-1}$.

The catalyst produced by the spontaneous deposition method and the catalyst produced by the Bönnemann method and heat treated in oxygen present similar cyclic voltammetric behavior, especially in the range, $0.4 \mathrm{~V}$ to $0.7 \mathrm{~V}$. This is of interest for direct methanol fuel cell applications. The catalyst synthesized by the Bönnemann method and heat treated only in hydrogen shows less electroactivity compared to the others.

\section{Conclusions}

The two methods are suitable for the production of electrocatalysts for fuel cell applications.

The catalysts synthesized by the Bönnemann method present good electrochemical activity and a structure consisting of well-dispersed nanocrystals on the carbon support, leading to good electrochemical behavior for fuel cells applications.

The catalysts synthesized by the spontaneous deposition method also present good electrochemical activity, if the amount of platinum in the catalyst is normalised. The structure of the catalyst consists of platinum atoms on carbon-supported ruthenium nanocrystals.

The colloidal method (Bönnemann) should be performed in an inert atmosphere with non-hydrated chlorides of the metals involved becoming more expensive than the spontaneous deposition method. On the other hand, the colloidal method could produce ternary and quaternary systems of catalysts to improve their performance towards CO contamination.

\section{Acknowledgments}

The 'Conselho Nacional de Desenvolvimento Científico e Tecnológico(CNPQ)', 'Fundação de Amparo a Pesquisa do Estado de São Paulo (FAPESP)', and 'Financiadora de Estudos e Projetos (FINEP - CTPETRO)' are greatfully acknowledged for their financial support, and the Technical University of Darmstadt for their laboratory support.

\section{References}

1. Linardi, M, Aricó, EM, Franco, EG, Célula de Energia. Revista de Química Industrial. 2001; 717:7-13.

2. Shropshire, A. Catalysis of Electrochemical Oxidation of Formaldehyde and Methanol by Molybdates. J. Electrochem. Soc. 1965; 112(5):465.

3. Gasteiger, HA, Markovic, N, Ross Jr, PN, Cairns, EJ. Carbon monoxide electrooxidation on well-characterized platinum-ruthenium alloys. $J$. Phys. Chem. 1994; 98:617-625.

4. Gasteiger, HA, Markovic, N, Ross Jr, PN. H2 and CO Electrooxidation on Well-Charactenzed Pt, Ru, and Pt-Ru. 1. Rotating Disk Electrode Studies of the Puré Gases Including Temperature Effects. J. Phys. Chem. 1995; 99:8290-8301.

5. Bönnemann, HW Brijoux, R Brinkmann, E Dinjus, T Joussen. B Korall. Erzeugung von kolloiden Übergangsmetallen in organischer Phase und ihre Anwendung in der Katalyse. Angew. Chem. 1991; 103:1344-1346.

6. Brankovic, SR, McBreen, J, Adzic, RR. Spontaneous deposition of Pt on the $\mathrm{Ru}(0001)$ surface. J. Electroanal. Chem. 2001; 503:99-104.

7. Brankovic, SR, Wang, JX, Adzic, RR. Pt Submonolayers on Ru Nanoparticles A Novel Low Pt Loading, High CO Tolerance Fuel Cell Electrocatalyst. Electrochem. and Solid-State Lett. 2001; 4:A217-A220.

8. Brankovic, SR, Wang, JX, Adzic, RR. New methods of controlled monolayer-to-multilayer deposition of Pt for designing electrocatalysts at an atomic level. J. Serb. Chem. Soc., 2001; 66(11-12):887-898.

9. Wendt, H, Götz, M, Linardi, M. Tecnologia de Células a Combustível. Química Nova. 2000; 23-4:538-546.

10. Franco, EG, Aricó, E, Linardi, M, Roth, C, Martz, N, Fuess, H. Synthesis and characterization of eletrocatalyst powders for application in PEM fuel cells; PTECH 2001, Third International Latin-American Conference on Powder Technology, Florianópolis, Brasil, November 2001.

11. Oliveira Neto, A, Franco, EG, Aricó, E, Linardi, M, Gonzalez,ER. Electro-oxidation of methanol and ethanol on Pt-Ru/C and Pt-Ru-Mo/C electrocatalysts prepared by Bonnemanns method. J. Europ. Ceramic Soc. 2003; 23:2987-2992.

12. Oliveira Neto, A, Franco, EG, Aricó, E, Spinacé, EV, Linardi, M. ElectroOxidation of Methanol and Ethanol on Pt-Ru/C and Pt-Ru-Ni/C based Electrocatalysts for PEM Fuel Cell Prepared by the Bönnemann's Method. Proccedings of Fuell Cells Science and Technology 2002 - Scientific Advances in Fuel Cells Systems, Amsterdam, Netherlands, 2002.

13. Franco, EG, Aricó, E, Linardi, M, Roth, C, Martz, N, Fuess, H. Synthesis and Characterization of Electrocatalyst Powders for Applications in PEM fuel Cells. Mater. Sci. Forum. 2003; 416(4):4-10.

14. Schmidt, TJ, Gasteiger, HA, Behm, RJ. Methanol electrooxidation on a colloidal PtRu-alloy fuel-cell catalyst. Electrochemistry Communications. $1999 ; 1(1): 1-4$.

15. Franco, EG, Oliveira Neto, A, Linardi, M, Aricó, E. Synthesis of Electrocatalysts by the Bönnemann Method for the Oxidation of Methanol and the Mixture H2/CO in a Proton Exchange Membrane Fuel Cell. $J$. Braz. Chem. Soc. 2002; 13:516-521.

16. Radmilovic, V, Gasteiger, HA, Ross Jr, P N. Structure and chemical composition of a supported Pt-Ru electrocatalysis for methanol oxidation. $J$. Catal. 1995; 154:98-106.

17. Lasch, K; Jörissen, L; Garche, J. The effect of metal oxides as co-catalysts for the electro-oxidation of methanol on platinum-ruthenium. J. Power Sources. 1999;84:225-230.

18. Steigerwalt, E.S., Deluga, G.A., Lukehart, C.M. Pt-Ru/Carbon Fiber Nanocomposites: Synthesis, Characterization, and Performance as Anode Catalysts of Direct Methanol Fuel Cells. A Search for Exceptional Performance. J. Phys. Chem. B. 2002; 106-4: 760.

19. Passalacqua, E, Lufrano, F, Squadrito, G, Patti, A, Giorgi, L. CO tolerance of Pt-W electrocatalysts for polymer electrolyte fuel cells. J. New Mat. Electrochem. Systems. 2000; 3: 141-146.

20. Rolinson, DR, Hagans, PL, Swider, KE, Long, JW. Role of Hydrous Ruthenium Oxide in Pt-Ru Direct Methanol Fuel Cell Anode Electrocatalysts: The Importance of Mixed Electron/Proton Conductivity. Langmuir. 1999; 15(3):774-779.

21. Schmidt, TJ, Noeske, M, Gasteiger, HA, Behm, RJ, Britz, P, Brijoux, W, Bönnemann, H. Langmuir 13, p. 2591, 1997. 